\title{
Treatment of extensive-stage small cell lung carcinoma: current status and future
} prospects

\author{
I.K. Demedts*, K.Y. Vermaelen*,\# and J.P. van Meerbeeck*,\#
}

ABSTRACT: Small cell lung cancer (SCLC) is an aggressive lung tumour strongly associated with cigarette smoking, with patients often presenting with metastatic disease at the time of diagnosis. Although SCLC is very chemoradiosensitive and high response rates are obtained with treatment, relapse rates are high and the prognosis remains very poor.

In limited-stage SCLC, the overall survival rate has been significantly improved by adding dosehyperfractionated thoracic radiotherapy and prophylactic cranial irradiation to systemic chemotherapy. In contrast, little progress has been made in the treatment of extensive-stage SCLC (ES-SCLC), apart from the recently documented survival gain by the addition of prophylactic cranial irradiation.

First-line therapy in ES-SCLC currently consists of chemotherapy, combining a platinum drug with either etoposide or irinotecan as a possible alternative.

New treatments are needed in order to improve the prognosis of ES-SCLC, as median survival with current standard treatment is still only 9-10 months from diagnosis. The present review focuses on the management of ES-SCLC, with special attention to the development of new treatment options.

KEYWORDS: Chemotherapy, extensive disease, radiotherapy, small cell lung cancer, treatment

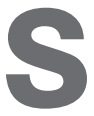
mall cell lung cancer (SCLC) is an aggressive malignant disease, with the majority of patients presenting with distant metastasis at diagnosis. A separate staging system has been developed for SCLC, classifying SCLC as limited or extensive disease [1]. The International Association for the Study of Lung Cancer defines limited-stage SCLC (LS-SCLC) as: “disease restricted to one hemithorax with regional lymph node metastases, including hilar, ipsilateral and contralateral mediastinal, and ipsilateral and contralateral supraclavicular nodes and should also include patients with ipsilateral pleural effusion independent of whether cytology is positive or negative" [2]. Patients with SCLC who do not fit this definition are considered to have extensive-stage SCLC (ES-SCLC). This staging system was used to select the appropriate treatment regimen: chemotherapy in combination with thoracic radiotherapy in patients with LSSCLC, and chemotherapy alone in patients with ES-SCLC. Recent data suggest that the tumour, node, metastasis classification traditionally reserved for the staging of nonsmall cell lung cancer (NSCLC) can also be applied for the staging of SCLC [3].

Previous articles in this series: No. 1: De Wever W, Stroobants S, Coden J, et al. Integrated PET/CT in the staging of nonsmall cell lung cancer: technical aspects and resection for lung cancer. Eur Respir J 2009; 33: 201-212. No. 2: Rami-Porta R, Tsuboi M. Sublobar resection for lung cancer. Eur Respir J 2009; 33: 426-435. No. 3: McWilliams A, Lam B, Sutedja T. Early proximal lung cancer diagnosis and treatment. Eur Respir J 2009; 33: 656-665. No. 4: Sculier J-P, Moro-Sibilot D. First- and second-line therapy for advanced nonsmall cell lung cancer. Eur Respir J 2009; 33: 916-930. No. 5: van Tilburg PMB, Stam H, Hoogsteden HC, et al. Pre-operative pulmonary evaluation of lung cancer patients: a review of the literature. Eur Respir J 2009; 33: 1206-1215. No. 6: Brambilla E, Gazdar A. Pathogenesis of lung cancer signalling pathways: roadmap for therapies. Eur Respir J 2009; 33: 1482-1494. No. 7: Horváth I, Lázár Z, Gyulai N, et al. Exhaled biomarkers in lung cancer. Eur Respir J 2009; 34: 261-275. No. 8: 0cak S, Sos ML, Thomas RK, et al. High-throughput molecular analysis in lung cancer: insights into biology and potential clinical applications. Eur Respir J 2009; 34: 489-506. No. 9: Field JK, Liloglou T, Niaz A. et al. EUELC project: a multi-centre, multipurpose study to investigate early stage NSCLC, and to establish a biobank for ongoing collaboration. Eur Respir J 2009; 34: 1477-1486. 
The present review addresses the systemic tumour-directed treatment of ES-SCLC. Recently, prophylactic cranial irradiation (PCI) has been shown to improve outcome in patients with ES-SCLC [4], but only small advances have been made otherwise.

\section{FIRST-LINE TREATMENT OF ES-SCLC}

Advances in imaging techniques have led to more accurate staging of SCLC, with a stage shift towards an increase in ESSCLC over LS-SCLC as more occult metastases are detected. If left untreated, patients with SCLC rarely survive longer than a few months [5], but chemotherapy dramatically prolongs survival compared to the best supportive care [6]. For patients with ES-SCLC, 60-80\% respond to chemotherapy, although complete remission is observed in only $15-20 \%$. From the time of diagnosis, the reported median survival range for ES-SCLC is 8-13 months (fig. 1).

As SCLC is a very chemosensitive tumour, rapid responses, with symptomatic improvement, are often seen with chemotherapy. This has important clinical implications as, in contrast to advanced-stage NSCLC, chemotherapy can also be offered to patients with SCLC and a poor or bad performance status (World Health Organization performance status of 2-3), since a rapid amelioration of the patient's symptoms and general condition can be expected together with an improved outcome [7]. However, the risk of toxicity is greater in this group than in patients with good performance status.

The first-line treatment of ES-SCLC currently consists of chemotherapy with a platinum derivative and etoposide, a combination that was first reported to be effective in the treatment of SCLC in 1985 [8, 9]. The superiority of the platinum/etoposide combination as first-line standard treatment is confirmed by two meta-analyses reporting a significant

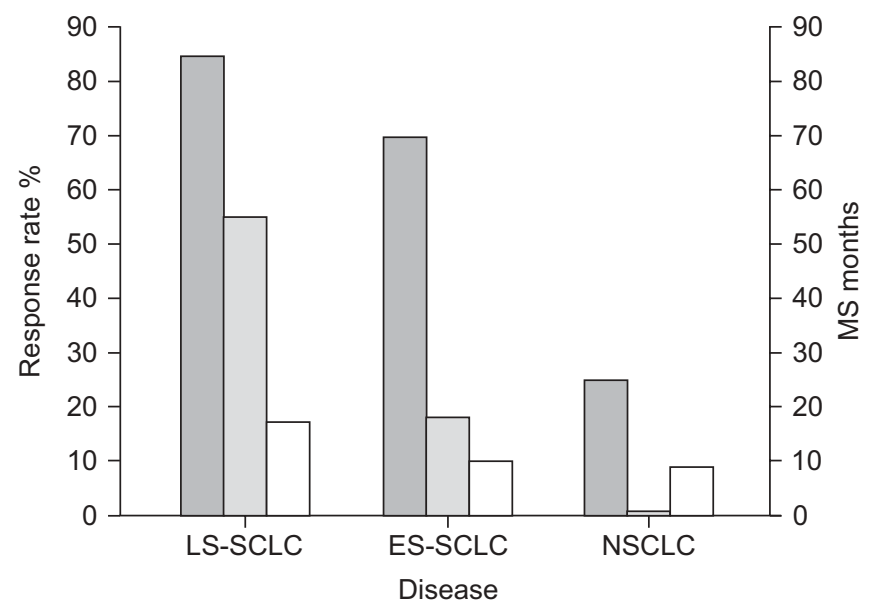

FIGURE 1. Response rates and median survival (MS; $\square$ ) in small cell lung cancer (SCLC) and nonsmall cell lung cancer (NSCLC). Response rates in SCLC are much higher than in NSCLC, although MS remains poor. The overall response ( $\square$ ) ranges $80-90 \%$ in limited-stage SCLC (LS-SCLC), 60-80\% in extensive-stage SCLC (ES-SCLC) and 20-28\% in advanced-stage NSCLC. Complete responses ( $)$ are noted in SCLC (50-60\% in LS-SCLC and 15-20\% in ES-SCLC), whereas this is almost never the case in NSCLC. Despite these impressive response rates MS is only 14-20 months in LS-SCLC and 8-13 months in ES-SCLC, compared to 8-11 months in advanced-stage NSCLC. survival benefit of platinum-based chemotherapy [10, 11] compared to chemotherapy without platinum compounds, contrary to the results of a third meta-analysis [12]. PujoL et al. [10] evaluated 19 trials ( $>4,000$ patients) and concluded that a platinum-containing regimen yields a higher response rate (odds ratio 1.35; 95\% confidence interval (CI) 1.18-1.55; $\mathrm{p}<1 \times 10^{-5}$ ) and reduction of risk of death at $1 \mathrm{yr}$ (odds ratio $0.80 ; 95 \%$ CI $0.69-0.93 ; p=0.002$ ) compared to chemotherapy involving other nonplatinum alkylating agents. These benefits were obtained without a significant increase in the rate of toxic deaths. These findings were confirmed by data from the European Lung Cancer Working Party (ELCWP) showing a survival benefit for patients treated with a combination of etoposide and cisplatin (EP) [11]. In this meta-analysis of 7,173 patients from 36 trials, the authors also demonstrated a survival benefit for treatment combinations with etoposide compared to a treatment without etoposide. Moreover, treatment regimens with cisplatin but without etoposide are probably not significantly better than regimens using neither drug, but only one trial in the meta-analysis formally compared these two treatments, and thus the clinical relevance of this finding is unclear [11].

In contrast with these findings, a recent meta-analysis in 5,530 patients from 29 trials by the Cochrane Collaboration suggested no significant benefit of platinum-based chemotherapy regimens compared with nonplatinum-based regimens [12]. There was no significant difference between the two treatment groups in terms of survival at 6,12 and 24 months. There was also no significant difference in terms of overall tumour response. However, platinum-based treatment regimens did have a significantly higher rate of complete response. Platinum-based chemotherapy regimens had significantly higher rates of nausea and vomiting, anaemia and thrombocytopenia [12]. Whereas the ELCWP meta-analysis [11] showed a survival benefit with EP, the Cochrane meta-analysis did not formally compare EP with other platinum-based regimens, providing a possible explanation for the divergent conclusions between the two meta-analyses. Importantly, neither of these meta-analyses used individual patient data from the original trials, and hence should be interpreted with caution. In a randomised phase III trial published in 2002 (and thus not included in the meta-analyses of PujOL et al. [10] and MASCAUX et al. [11]), SUNDSTRøM et al. [13] compared treatment with EP to that with cyclophosphamide, epirubicin and vincristine, and documented significantly higher 2- and 5-yr survival rates in the EP arm in LS-SCLC. A trend in survival benefit was seen in the patients with ES-SCLC, with a median survival of 6.5 months in the cyclophosphamide, epirubicin and vincristine group compared to 8.4 months in the EP group.

A well-known and important side-effect of cisplatin is its nephrotoxicity, for which prevention hyperhydration is required. This can be problematic in the more fragile and elderly patient or in patients with cardiac or renal comorbidity. This led several authors to investigate whether an association of etoposide with carboplatin, which is less toxic than cisplatin, has a comparable outcome to EP. Only one randomised phase III trial directly compared these two treatment regimens. The Hellenic Cooperative Oncology Group conducted a randomised phase III trial that compared the efficacy and toxicity of EP versus etoposide/carboplatin in previously untreated patients 
with SCLC (both LS- and ES-SCLC) [14, 15]. These authors demonstrated that carboplatin in combination with etoposide was as effective as, but less toxic than, EP. They concluded that these results provide a rationale for the use of the etoposide/ carboplatin combination over EP because of similar efficacy and decreased toxicity.

There is some controversy as to whether etoposide should preferably be administered intravenously or as on oral formulation. Although an oral formulation of etoposide exists and seems an attractive alternative at first sight, several studies have demonstrated that oral etoposide was less effective and sometimes more toxic than using intravenous administration. Two randomised trials were prematurely stopped because of inferior survival with oral etoposide at the interim analysis [16, 17]. Unpredictable events may be linked to variable bioavailability of the oral formulation.

\section{ALTERNATIVES TO PLATIN/ETOPOSIDE}

Despite the high response rates in patients with SCLC treated with cis- or carboplatin in combination with etoposide, relapse rates are high and the overall prognosis remains poor (fig. 1). The most likely explanation for this problem is the rapid development of drug resistance, probably due to the selection of a small number of residual tumour cells that are not sensitive to the initial chemotherapy. The fact that response rates during second-line chemotherapy are much lower is attributable to cross-resistance between the different drugs used.

For this reason, several other therapeutic regimens have been evaluated in the treatment of ES-SCLC. Anthracyclines, camptothecins, antifolates and taxane have all been tested as possible alternatives in the first-line treatment of ES-SCLC (table 1).

Doxorubicin-containing regimens have been used for a long time in the treatment of SCLC. However, recently published phase III randomised trials failed to demonstrate better overall survival with these regimens compared to platinum-based chemotherapy $[29,30]$.

Importantly, haematological toxicity was significantly higher with doxorubicin-containing regimens, leading to more episodes of febrile neutropenia and more hospital admissions. It should be mentioned that these side-effects can be managed much better nowadays, with the use of prophylactic antibiotics and growth factors.

Epirubicin, a modified anthracycline that is less cardiotoxic than doxorubicin [31], has demonstrated significant activity as a single agent in SCLC in phase II studies. A randomised phase III trial, including 207 patients with LS-SCLC and 192 patients with ES-SCLC, comparing cisplatin/epirubicin $\left(100 \mathrm{mg} \cdot \mathrm{m}^{-2}\right)$ to EP demonstrated similar overall objective response rates, median time to progression and median survival, whereas haematological toxicity was lower in patients treated with epirubicin [22]. The combination of epirubicin and cisplatin is considered a reasonable alternative regimen for the treatment of patients with SCLC. A practical advantage is that epirubicin can be administered in 1 day, whereas etoposide is administered over 3 days consecutively.

Promising results in the treatment of ES-SCLC have been obtained in phase I and phase II trials (mainly in Japan) with amrubicin, another synthetic anthracycline [32, 33]. Randomised trials are currently recruiting patients in order to confirm these findings and to evaluate whether there is a role for amrubicin, in first-line therapy as well as in relapsed disease $[34,35]$.

Promising results were obtained with irinotecan, a camptothecin that acts as a topoisomerase I inhibitor. In 2002, a Japanese phase III trial suggested that the combination of cisplatin plus irinotecan

TABLE 1 Outcome of first-line platinum-based combination chemotherapy phase III trials in extensive-stage small cell lung cancer

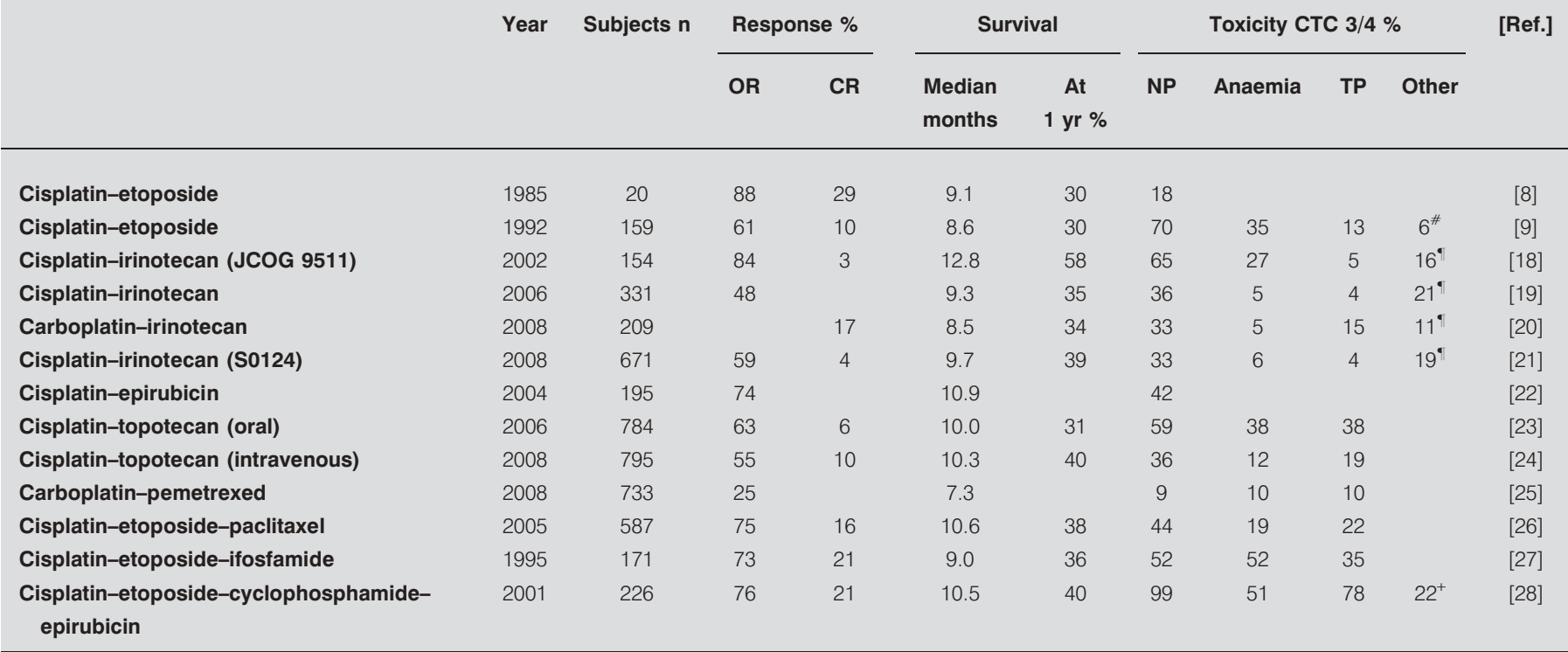

OR: overall response; CR: complete response; CTC: common toxicity criteria; NP: neutropenia; TP: thrombocytopenia; JCOG: Japanese Clinical Oncology Group. \#: nausea/vomiting; " diarrhoea; ${ }^{+}$: infections. 
was significantly more effective than EP [18]. Indeed, this trial was prematurely stopped because, at an interim analysis, the 154 patients treated with irinotecan plus cisplatin showed a significantly higher response rate (84 versus 68\%), longer median survival (12.8 versus 9.4 months) and higher 2 -yr survival rate (19 versus $5 \%$ ) than those with the etoposide-based regimen. Although haematological toxicity was less pronounced with irinotecan, significantly more grade 3 or 4 diarrhoea was reported in this group. However, these results could not be confirmed in a large phase III trial in patients from the USA, Australia and Canada [19]. This study included 322 patients and could not safely administer the same doses as in Japan and thus used a different regimen for the administration of both EP and cisplatin/ irinotecan but with a similar if not higher dose intensity. In order to rule out an effect due to these differences in the treatment schedule, the Southwest Oncology Group (SWOG) trial S0124 randomly assigned 671 patients with ES-SCLC to regimens identical to those used in the Japanese trial. The results of this trial were published recently [21]; no significant differences were found in overall objective response rates, overall survival or 1-yr survival between the two treatment arms. Finally, a fourth study from Norway addressing this issue was published in 2008, reporting a moderate benefit of a treatment with carboplatin and irinotecan over carboplatin with oral etoposide [20]. In summary, conflicting results have been obtained with the combination of platinum and irinotecan, probably due to pharmacogenomic differences between study populations, as well as differences in the studied treatment regimens and their pharmacokinetics. Especially with regard to the toxicity of irinotecan, genetic differences in, for example, the metabolic enzyme uridinediphosphate glucuronosyltransferase (UGT) 1A1, might influence the degree of expected drug toxicity. In the SWOG S0124 trial, pharmacogenomic analysis showed that the TT genotype of the 3435C > T ABCB1 (ATP-binding cassette, subfamily B (MDR/ $\mathrm{TAP})$, member 1 gene) polymorphism (membrane transport) was associated with cisplatin/irinotecan-related diarrhoea, whereas the AA genotype of the $-3156 \mathrm{G}>\mathrm{A}$ UGT1A1 polymorphism (drug metabolism) was associated with cisplatin/irinotecan-related neutropenia. However, recent data question the validity of measuring a single polymorphism (UGT1A1) to predict drug elimination and toxicity, since other polymorphisms and single nucleotide polymorphisms also influence the disposition of irinotecan [36]. Moreover, in this series, half of the variation in toxicity and drug exposure remains unexplained by the UGT1A1 genotype.

Topotecan, another member of the camptothecin family, has been evaluated in several phase II and III trials as first-line therapy for ES-SCLC in comparison with the standard treatment of EP [23, 24, 37]. These trials concluded noninferiority of cisplatin/topotecan compared to EP with regard to overall survival. ECKARDT et al. [23] demonstrated that both regimens were similarly tolerable. Grade $3 / 4$ neutropenia occurred more frequently with EP (84 versus 59\%), whereas grade $3 / 4$ anaemia and thrombocytopenia occurred more frequently with cisplatin/topotecan (38 versus $21 \%$ and 38 versus $23 \%$, respectively). In the study of HEIGENER et al. [24], increased haematological toxicity was observed with topotecan. The number of toxicity-related deaths was numerically higher with cisplatin/topotecan (5\%) compared to EP (3\%). Moreover, a third treatment arm with the combination of topotecan and etoposide was abandoned due to an increased number of treatment-related deaths.

Belotecan, a new camptothecin analogue, has shown activity in SCLC in phase II trials [38]. Currently, a phase III trial comparing EP with cisplatin/belotecan in patients with previously untreated ES-SCLC is running in Asia [39].

Pemetrexed, a folic acid metabolism antagonist that has a place in the first-line treatment of malignant mesothelioma and possibly also of nonsquamous NSCLC, has also been evaluated in the treatment of SCLC. Data from phase I and II trials suggested antitumoural activity and toxicity comparable to standard treatment regimens with EP or cisplatin/irinotecan [25]. However, an interim analysis of a phase III trial revealed inferiority of carboplatin/pemetrexed compared to carboplatin/ etoposide and led to the interruption of that trial [40].

Paclitaxel, a member of the taxane family, has also been investigated in the treatment of SCLC. There is some evidence of non-cross-resistance to paclitaxel from phase II studies, which described a $29 \%$ response rate to paclitaxel in chemotherapyrefractory ES-SCLC [41]. The combination of carboplatin and paclitaxel was compared to a treatment with cyclophosphamide, doxorubicin and etoposide by DE JONG et al. [29], but did not result in better survival, whereas haematological toxicity was significantly lower with carboplatin/paclitaxel compared to cyclophosphamide, doxorubicin and etoposide. The addition of paclitaxel to first-line treatment with EP did not improve the time to progression or survival in patients with ES-SCLC compared with EP alone, and was associated with unacceptable toxicity [26, 42]. At present, there are no data available that directly compare the combination of paclitaxel and a platinum compound to the standard treatment with platinum and etoposide.

The addition of ifosfamide [27] or even a combination of cyclophosphamide and epirubicin [28] to the standard treatment with EP has led to higher response rates and modestly prolonged survival, but at the cost of increased toxicity. At present, there are insufficient data to justify the addition of a third or even fourth drug to the platinum-etoposide backbone for ES-SCLC.

\section{DOSE MODIFICATION AND SEQUENCE ALTERATION Increasing dose intensity}

Some groups have tried to eradicate all malignant cells by increasing the dose intensity of chemotherapy, exploiting the concept that the dose-response relationship in SCLC might be linear [43, 44]. This increase can be achieved by either increasing the total drug dose for one or more cycles, decreasing the interval between drugs or cycles or a combination of the two. In all approaches, myeloid growth factors can be used to avoid excessive haematological toxicity. This strategy can be pushed to the limits by administering chemotherapy at myeloablative doses, followed by bone marrow reconstitution with autologous haematopoietic stem cells.

IHDE et al. [45] compared high- and standard-dose EP chemotherapy in patients with ES-SCLC. Despite the higher relative dose intensity that was given in the high-dose chemotherapy group, complete response rates (23 versus $22 \%$; $\mathrm{p}=0.99)$ and median survival (10.7 and 11.4 months, respectively; $\mathrm{p}=0.68$ ) were almost identical, whereas significantly 
more haematological toxicity was noted in the high-dose chemotherapy group. In order to overcome the problem of increased haematological toxicity, the use of myeloid growth factors has been proposed and evaluated in several phase III trials. Using myeloid growth factors permits the administration of higher dose intensities, but has not unequivocally been demonstrated to result in increased overall survival, and haematological toxicity remains significantly higher [46, 47]. A meta-analysis on this topic concluded that there is no place for the routine use of haematological colony-stimulating factors in the treatment of SCLC for the purpose of increasing dose intensity [48], although there is a role for growth factors for the prevention of infection. Two phase III trials, including both patients with LS- and with ES-SCLC, demonstrated increased haematological toxicity but no improved survival when combining myeloablative chemotherapy with autologous haematopoietic stem cell reinfusion $[49,50]$.

A last theoretical concept for avoiding rapid relapse is the consolidation of an initially favourable response by the continued administration of the initial drug (maintenance) [51] or the immediate administration of a second drug directly after the first chemotherapy regimen (early second line) [52]. Once again, clinical trials have failed to show a clear benefit for these at-least-theoretically promising strategies. Two metaanalyses evaluated the potential use of maintenance chemotherapy in SCLC. SCULIER et al. [53], in 1998, selected 13 published randomised trials, of which only one showed a significant difference in survival in favour of maintenance. Five trials described some survival advantages in subgroups of patients, one showed a significantly shorter survival with maintenance and, in six studies, there was no difference between the two arms. The overall quality of the trials was considered poor, and a quantitative meta-analysis was not possible because of the lack of data for calculation of the odds ratio and because of the heterogeneity in the design of the studies. BozCUK et al. [54], in 2005, analysed 14 trials (11 of these were also included in the meta-analysis of SCULIER et al. [53]), of which only four resulted in significant differences as far as direct comparisons between maintenance and follow-up arms were concerned; three trials documented better overall survival with maintenance chemotherapy and one showed worse overall survival with maintenance chemotherapy, whereas 10 did not find significant differences regarding overall survival. However, in the meta-analysis of BozCuK et al. [54], including 2,550 patients, both 1- and 2-yr mortality were reduced with maintenance/consolidation chemotherapy. Importantly, some of the trials showed increased toxicity (mostly myelosuppression) with the use of maintenance regimens, indicating that the benefit and toxicity from this approach should be balanced carefully $[53,54]$. The authors of both meta-analyses concluded that maintenance chemotherapy could be useful in SCLC, but that new randomised clinical trials of high quality are required in order to further resolve this question. Analogous to the treatment of advanced NSCLC [55], maintenance treatment for SCLC must still be considered investigational.

\section{Alternating or sequential administration of chemotherapy}

Another approach to avoiding cross-resistance is the use of presumed non-cross-resistant regimens that are effective against SCLC in an alternating or sequential manner. However, several phase III trials have failed to demonstrate a significant survival benefit using this approach $[9,56]$. In the European Organization for Research and Treatment of Cancer (EORTC) trial of POSTMUs et al. [56], the use of two alternating regimens with a proven degree of non-cross-resistance did not result in any improvement in survival in patients with ESSCLC.

\section{OTHER APPROACHES: ADDITION OF AGENTS WHOSE PRIMARY ACTIVITY IS NOT ANTITUMOURAL}

Treatment with anticoagulants might improve outcomes in cancer patients through an antitumour effect in addition to their antithrombotic effect. A Cochrane analysis concluded that there is no mortality benefit from oral anticoagulation in patients with cancer in general. In patients with SCLC, however, the evidence suggested a potential mortality benefit from warfarin at 6 months, particularly in extensive disease, but this occurred at the cost of an increased risk of major and minor bleeding [57]. A more recent review suggested a survival benefit of parenteral anticoagulation with heparin in cancer patients in general, and in patients with LS-SCLC in particular [58]. A randomised phase III trial investigating the use of enoxaparin in SCLC is currently recruiting patients in Sweden [59], and the FRAGMATIC trial in the UK includes both patients with NSCLC and with SCLC in order to evaluate whether the addition of dalteparin to standard treatment increases overall survival [60].

In preclinical studies of SCLC, simvastatin suppresses growth, induces apoptosis and enhances sensitivity to etoposide [61]. Pravastatin may stop the growth of tumour cells by blocking some of the enzymes needed for cell growth and by making tumour cells more sensitive to chemotherapy [62, 63]. A randomised controlled phase III trial investigating the addition of pravastatin to standard first-line treatment in SCLC is currently accruing in the UK [64].

\section{NEW DRUGS}

Picoplatin is a platinum analogue designed to overcome platinum resistance, with some activity in relapsed SCLC, as shown in a previous phase II trial conducted in refractory resistant and sensitive patients [65]. Compared to other platinum agents, picoplatin causes much less nephro-, neuroand ototoxicity in phase I and II trials [66]. A phase III study (the Study of Picoplatin Efficacy After Relapse (SPEAR) trial) is currently evaluating picoplatin plus best supportive care versus best supportive care alone in both refractory and relapsed patients [67].

New approaches to targeting SCLC in order to improve drug delivery to malignant cells are also being evaluated in clinical trials. CD56, for example, is a cell surface protein expressed on the majority of SCLC cells. A phase II clinical trial evaluating the efficacy of an anti-CD56 antibody conjugated to a cytotoxic drug, maytansinoid, is underway.

Obatoclax, a Bcl-2 inhibitor, is currently being evaluated in phase I/II trials including patients with SCLC $[68,69]$.

Temozolamide is an oral alkylating agent with proven efficacy in the treatment of malignant glioma. It is currently being 
TABLE 2 Randomised trials of second-line treatment of small cell lung cancer

\begin{tabular}{|c|c|c|c|c|c|c|c|c|c|c|}
\hline \multirow[t]{2}{*}{ Regimen } & \multirow[t]{2}{*}{ Year } & \multirow[t]{2}{*}{ Phase } & \multirow[t]{2}{*}{ Patients $\mathrm{n}$} & \multicolumn{4}{|c|}{ Response rate \% } & \multirow{2}{*}{$\begin{array}{c}\text { TTP } \\
\text { weeks }\end{array}$} & \multirow{2}{*}{$\begin{array}{c}\text { Survival } \\
\text { weeks }\end{array}$} & \multirow[t]{2}{*}{ [Ref.] } \\
\hline & & & & OR & CR & PR & SD & & & \\
\hline CAV versus topotecan & 1999 & $\|$ & $104 / 107$ & $18 / 24$ & $1 / 0$ & $17 / 24$ & $12 / 20$ & $-1-$ & $25 / 25$ & [71] \\
\hline Topotecan, oral versus intravenous & 2001 & $\|$ & $52 / 54$ & $23 / 15$ & $2 / 4$ & $21 / 11$ & $19 / 30$ & $15 / 13$ & $32 / 25$ & [75] \\
\hline Topotecan, oral versus intravenous & 2007 & III & $155 / 154$ & $18 / 22$ & $1 / 0$ & $17 / 22$ & $18 / 23$ & $12 / 15$ & $33 / 35$ & [74] \\
\hline
\end{tabular}

Time to progression (TTP) and survival are presented as medians. OR: overall response; CR: complete response; PR: partial response; SD: stable disease; CAV cyclophosphamide, doxorubicin and vincristine; BSC: best supportive care.

evaluated in a phase II trial as a treatment for patients with relapsed SCLC [70].

\section{SECOND-LINE TREATMENT FOR ES-SCLC}

As mentioned above, high relapse rates are typical for SCLC. Different patterns of relapse have been described, classifying patients into three different groups, although the validity and utility of this has been questioned recently. Sensitive patients are those with a response to first-line therapy and a treatmentfree interval of $\geqslant 90$ days, whereas resistant patients relapse within 90 days following an initial response. Refractory patients do not respond at all to first-line treatment.

Single-agent topotecan is currently the only approved drug for the treatment of patients with SCLC who have failed or relapsed after first-line chemotherapy, and a combination of cyclophosphamide, doxorubicin and vincristine may also be used following first-line treatment with EP [71, 72].

Topotecan is available as an intravenous and, more recently, an oral formulation. VON PAWEL et al. [71] compared single-agent intravenous topotecan with the cyclophosphamide, doxorubicin and vincristine regimen in sensitive patients. Results with both types of treatment were comparable; the response rates were 24 and $18 \%$, and median survival was 25.0 and 24.7 weeks for topotecan and cyclophosphamide, doxorubicin and vincristine, respectively. Topotecan, however, provided greater symptom improvement in terms of improved dyspnoea, anorexia, fatigue, insomnia and daily activity.

A randomised controlled trial published in 2006 demonstrated that chemotherapy with oral topotecan is associated with improved survival and quality of life in patients with relapsed SCLC compared to best supportive care [73]. Treatment with oral topotecan has obvious advantages over intravenous treatment, and has been shown to exhibit similar activity and tolerability to intravenous topotecan [74, 75]. Taken together, these data (summarised in table 2) have led to the official registration of topotecan (either intravenous or oral) as a second-line treatment for SCLC, with response rates of $10-40 \%$ and a median survival time of 6.0 months [71, 73].

Several other cytotoxic agents, including taxanes, gemcitabine, vinorelbine, irinotecan and pemetrexed, have been investigated as second-line treatment, in either single-agent or combination treatment (table 3) [41, 65, 76-90]. Some agents, such as paclitaxel and irinotecan, have shown some degree of activity in phase II trials. However, these trials have only included a relatively small number of patients and most often there was an uneven distribution of sensitive versus refractory disease. The lack of comparative phase III trials precludes any formal conclusions.

Several trials with amrubicin have shown impressive results for the second-line treatment of relapsed SCLC. High response rates $(37-60 \%)$ have been reported for single-agent amrubicin in three Japanese phase II trials [86-88]. Interestingly, the response rate and median survival were similar in both sensitive and resistant patients. A phase II trial in the USA has investigated single-agent amrubicin in patients with refractory or resistant SCLC [89]. Activity was observed, and the most frequently observed toxicity was myelosuppression, but no anthracycline-induced cardiotoxicity was noted.

A randomised phase II trial has compared amrubicin and topotecan in previously treated SCLC. This study further supports the efficacy of amrubicin in both sensitive (overall response 53\%) and resistant patients (overall response 17\%). A higher response rate was achieved with amrubicin than with topotecan [90]. Further evaluation is currently ongoing within a phase III setting [34].

\section{RADIOTHERAPY IN ES-SCLC}

Thoracic radiotherapy is traditionally reserved for LS-SCLC, where the addition of chest irradiation to chemotherapy results in better local control and improved survival [91]. However, there is some preliminary evidence that adding thoracic radiotherapy to chemotherapy improves the survival of patients with ES-SCLC that respond to an initial three cycles of platinum/etoposide chemotherapy with a complete response outside the thorax and an at-least-partial response in the thorax [92]. These favourable results were obtained from a single-centre trial and require replication in a multicentric setting. A randomised trial addressing this issue is currently ongoing [93].

Although routine use of thoracic radiotherapy in ES-SCLC should not yet be integrated into the standard care of patients, there is more convincing evidence for offering PCI to patients with ES-SCLC. In 2007, the EORTC published a landmark trial that clearly demonstrated the usefulness of PCI in ES-SCLC [4]. They demonstrated that, in patients with ES-SCLC who responded to chemotherapy, PCI reduced the risk of brain metastases at 1 yr by $26 \%$ ( $40 \%$ brain metastases in control 


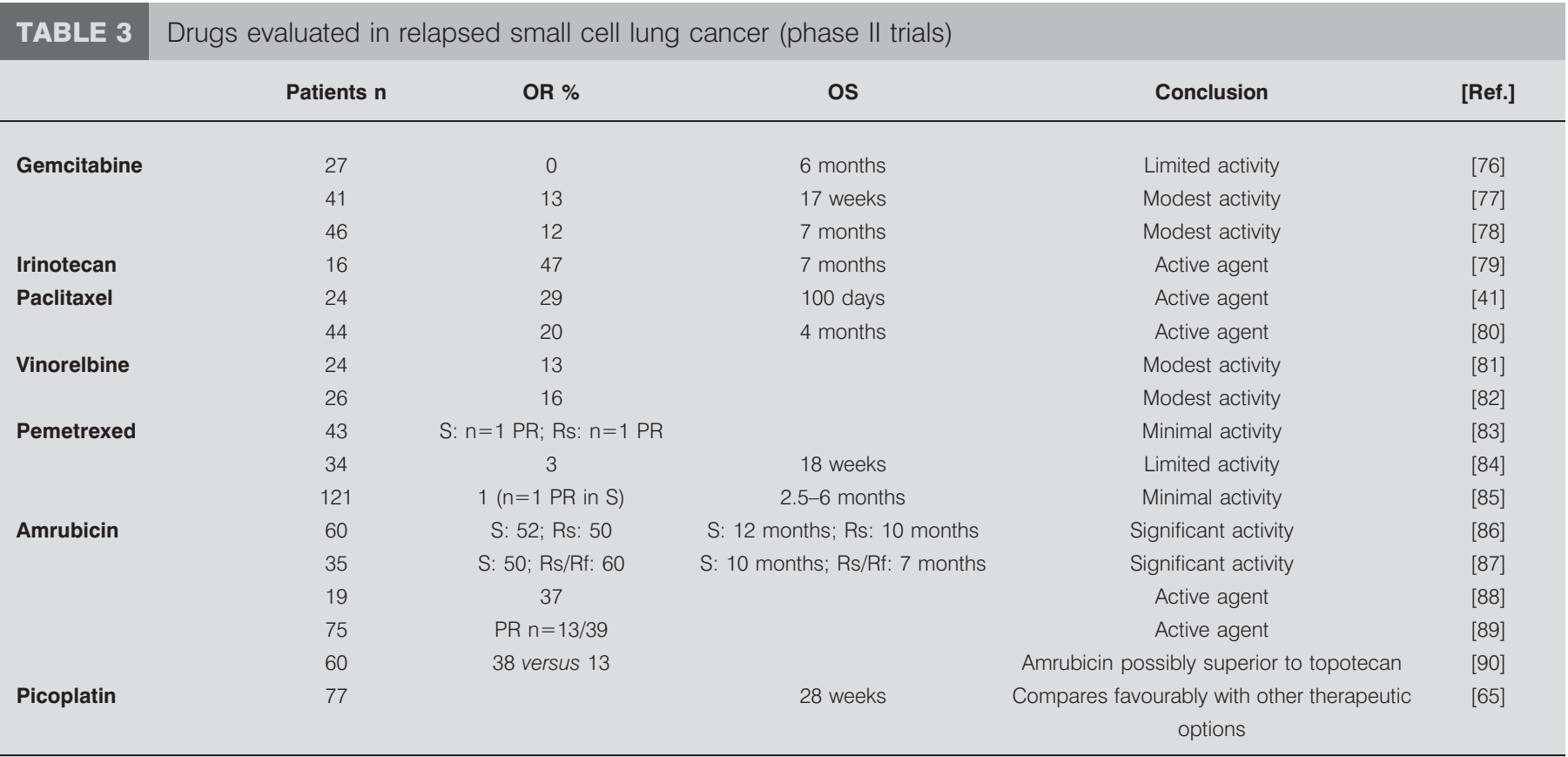

OR: overall response; OS: overall survival; PR: partial response; S: sensitive (initially responded and then relapsed/progressed within 60-180 days); Rs: resistant (initially responded to first-line platinum-containing chemotherapy and then relapsed/progressed within 60-90 days); Rf: refractory (failed or progressed with first-line platinumcontaining chemotherapy).

group versus $15 \%$ in PCI group). Moreover, the 1-yr survival rate was $27 \%$ in the irradiation group and $13 \%$ in the control group; in other words, PCI offers a $14 \%$ survival gain at $1 \mathrm{yr}$. In a recently published study of SLOTMAN et al. [94], the mean global health status score was 8 points higher in the PCI group, a difference that is below the cut-off of a 10-point difference for clinical significance. The most important side-effects of PCI were fatigue and hair loss, whereas the impact on other healthrelated quality-of-life aspects, such as cognitive and emotional functioning, was limited [94]. Hence it seems reasonable to offer PCI to all patients with ES-SCLC who respond to induction first-line chemotherapy.

\section{TARGETED THERAPIES}

Several targeted therapies have been evaluated in the treatment of SCLC (table 4), but, in contrast to advanced-stage NSCLC, none of these have yet made their way into daily clinical practice.

Epidermal growth factor receptor (EGFR) antagonists, such as erlotinib and gefitinib, have been proven to be effective in NSCLC, and were the first targeted agents to be used in the treatment of NSCLC. However, tumoural cells in SCLC either do not express the EGFR or express very small amounts [109], and clinical trials have not shown any benefit of treatment with EGFR inhibitors in SCLC [95].

Bevacizumab, a monoclonal antibody that binds vascular endothelial growth factor (VEGF), is currently being used in the treatment of advanced-stage NSCLC [110], and is now also being evaluated in SCLC [101-103]. Final results of two cooperative group phase II trials evaluating the use of bevacizumab in the treatment of ES-SCLC are pending [101, 102].
Vandetanib is an orally bioavailable inhibitor of VEGF receptor 2 (VEGFR-2 or kinase insert domain receptor (KDR)) and, to a lesser extent, EGFR [111]. Vandetanib was evaluated in a phase II trial, in which 107 patients who exhibited a partial or complete response to their induction therapy were randomly assigned to vandetanib or placebo [104]. Vandetanib failed to demonstrate efficacy as maintenance therapy for SCLC.

Sorafenib, a multikinase inhibitor affecting pathways involved in tumour progression and angiogenesis, has some promising activity in ES-SCLC [105], whereas the antiangiogenic agent cediranib (an inhibitor of the VEGFR-1, -2 and -3 tyrosine kinases) does not appear to be beneficial when added to standard chemotherapy [104].

Thalidomide, another antiangiogenic agent, has shown promising results as first-line chemotherapy and as maintenance therapy in phase II trials [107, 112]. However, two large randomised phase III trials failed to show a significant benefit of thalidomide in the treatment of SCLC [106, 113].

Temsirolimus, an inhibitor of the mammalian target of rapamycin, was evaluated as maintenance therapy in ESSCLC in a phase II Eastern Cooperative Oncology Group trial. Patients with either stable or responding disease following induction chemotherapy were treated with temsirolimus, but this seemed not to increase progression-free survival in this patient population [114].

Stem cell factor is coexpressed with its tyrosine kinase receptor (c-kit) on SCLC tumoural cells [115]. Treatment of SCLC cell lines with imatinib, a small-molecule inhibitor of several receptor tyrosine kinases, including c-kit, inhibited tumoural cell growth [116]. Despite these promising in vitro results, 


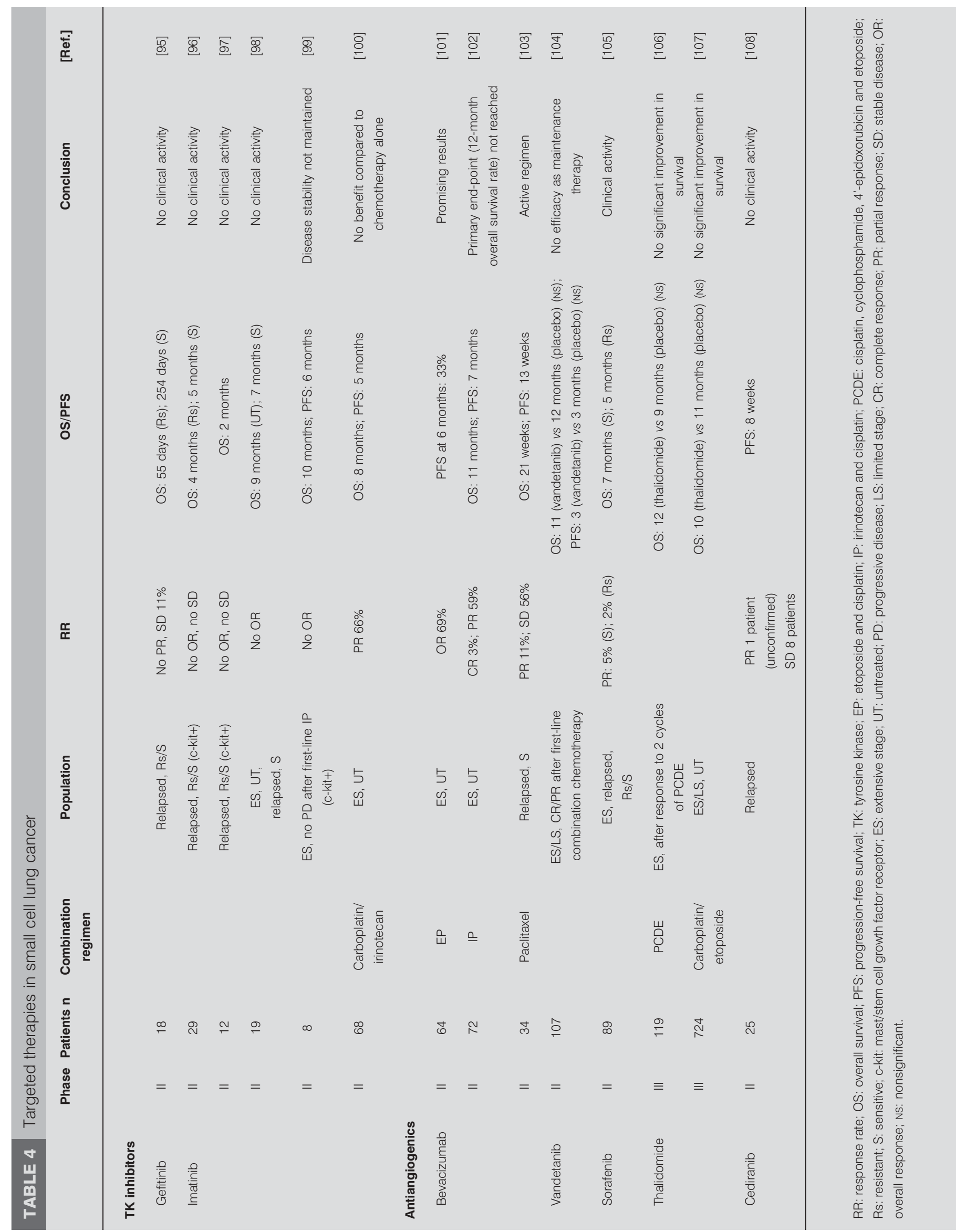




\begin{tabular}{|c|c|c|c|c|}
\hline & ACCP & ESMO & NICE & $\mathrm{NCCN}$ \\
\hline First-line treatment & $\begin{array}{l}\text { 4-6 cycles of platinum-based } \\
\text { chemotherapy } \\
\text { Platin with etoposide or irinotecan }\end{array}$ & $\begin{array}{c}\text { 4-6 cycles of platinum-based } \\
\text { chemotherapy } \\
\text { Platin with etoposide }\end{array}$ & $\begin{array}{l}\text { 4-6 cycles of platinum-based } \\
\text { chemotherapy } \\
\text { Preferred combination } \\
\text { not specified }\end{array}$ & 4-6 cycles of EP, EC, IP, IC or CAV \\
\hline $\mathrm{PCl}$ & Patients with $\mathrm{CR}$ & $\begin{array}{c}\text { Patients with major response } \\
\text { after chemotherapy }\end{array}$ & $\begin{array}{l}\text { To be evaluated in clinical } \\
\text { trials }\end{array}$ & $\begin{array}{c}\text { Patients with CR or near-CR } \\
\text { Not when multiple comorbid } \\
\text { conditions, poor PS or impaired } \\
\text { mental function }\end{array}$ \\
\hline Thoracic radiotherapy & $\begin{array}{l}\text { Patients with CR outside } \\
\text { chest and } C R \text { or PR in chest }\end{array}$ & Not discussed & $\begin{array}{l}\text { Patients with CR outside } \\
\text { chest and CR or PR in chest }\end{array}$ & $\begin{array}{l}\text { Patients with low-bulk metastatic } \\
\text { disease and CR or near-CR }\end{array}$ \\
\hline
\end{tabular}

ACCP: American College of Chest Physicians; ESMO: European Society for Medical Oncology; NICE: UK National Institute for Clinical Excellence; NCCN: National Comprehensive Cancer Network; PCI: prophylactic cranial irradiation; EP: etoposide and cisplatin; EC: etoposide and carboplatin; IP: irinotecan and cisplatin; IC: irinotecan and carboplatin; CAV: cyclophosphamide, doxorubicin and vincristine; CR: complete response; PS: performance status; PR: partial response.

phase II trials failed to show any benefit from adding imatinib to chemotherapy [96-100].

Matrix metalloproteinases (MMPs) are proteolytic enzymes that are released by stromal and tumoural cells. MMPs are able to degrade the extracellular matrix, and thus permit the migration of tumoural cells through the extracellular matrix, leading to their dissemination and the development of metastatic disease. Increased expression of metalloproteinases is associated with poor prognosis in SCLC [117]. However, clinical trials with two different MMP inhibitors (marimastat and BAY 12-9566) demonstrated no improved survival, and even a detrimental effect on quality of life [118, 119].

SCLC cells express several antigens belonging to the ganglioside family (polysialic acid, fucosyl GM1, GM2, GD2 and GD3). These antigens are not expressed on normal tissue and are thus interesting targets for vaccine therapy. Once again, however, phase III trials in SCLC with vaccine therapy targeted against these gangliosides have failed to show any benefit from this approach [120].

Another kind of targeted therapy is the use of antisense oligonucleotides, which target specific RNA sequences of genes involved in tumoural cell growth. Oblimersen is an antisense oligonucleotide that targets $\mathrm{Bcl}-2$, an inhibitor of apoptotic cell death that is highly expressed in SCLC. In vitro studies suggest that antisense oligonucleotides directed against Bcl-2 induce apoptosis and enhance the cytotoxicity of chemotherapeutic agents in SCLC cell lines [121, 122]. A multicentric randomised phase II trial found no evidence of improvement in response rate or overall survival when oblimersen was combined with carboplatin plus etoposide compared to chemotherapy alone [123]. Indeed, the proportion of patients alive at 1 yr was $24 \%$ with oblimersen and $47 \%$ without oblimersen, suggesting a worse outcome for patients receiving this drug.
GUIDELINES FROM INTERNATIONAL ORGANISATIONS

Several international cancer organisations have issued guidelines and recommendations for the treatment of ES-SCLC. The American College of Chest Physicians [124], European Society for Medical Oncology [125], UK National Institute for Clinical Excellence [126] and National Comprehensive Cancer Network [127], an alliance of 21 leading cancer centres in the USA, have all published new guidelines on the treatment of ES-SCLC. These guidelines are updated on a regular basis and are summarised in table 5 .

\section{HOPE FOR THE FUTURE?}

Despite all of the efforts illustrated above, little advance has been made in the treatment of ES-SCLC (fig. 2). The standard treatment with platin/etoposide has been unbeaten for $>20$ yrs. Increasing dose intensity, adding a third or even a fourth drug, alternating drug regimens and maintenance chemotherapy fail to improve overall survival. For the moment, targeted therapies have not (yet) been as successful for SCLC as for NSCLC. Unexpectedly, the most important progress in the treatment of ES-SCLC results from the introduction of PCI, resulting in a $14 \%$ survival gain at $1 \mathrm{yr}$.

There is no room for despair, however. Decreased incidence of smoking will decrease the incidence of SCLC in Western countries. Moreover, numerous phase I/II evaluations of drugs with potential activity in SCLC are underway. These include inhibitors of proteins highly expressed in SCLC, such as the receptor tyrosine kinases hepatocyte growth factor receptor, c-src and insulin-like growth factor-I receptor. Picornavirus Seneca Valley Virus-001, an oncolytic virus with selective tropism for neuroendocrine cells, is currently undergoing phase I evaluation. Embryonic signalling pathways, such as the hedgehog pathway, are implicated in normal and tumour stem cell maintenance. Inhibitors of this pathway are currently in phase I trials. Epigenetic modulation through DNA 


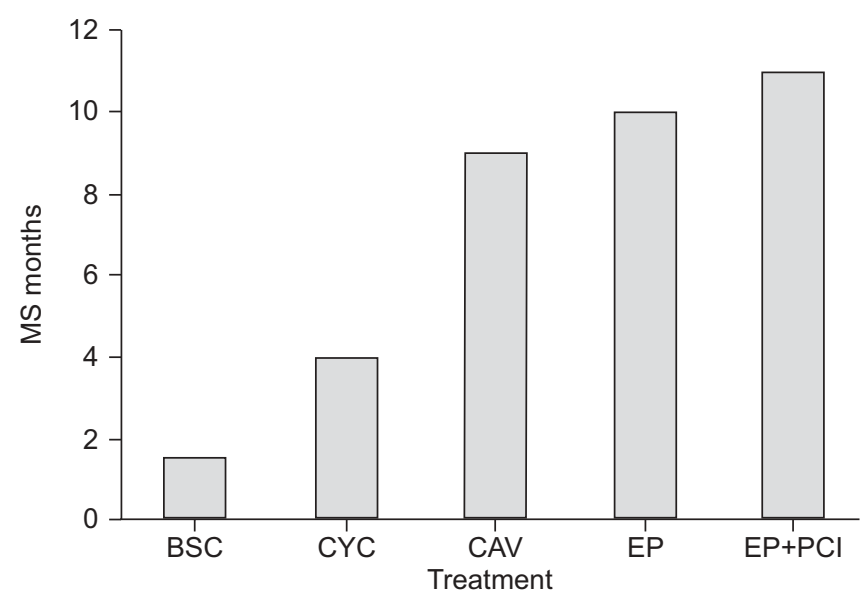

FIGURE 2. Median survival (MS) in extensive-stage small cell lung cancer with various treatments developed since the 1960s. BSC: best supportive care; CYC: cyclophosphamide; CAV: cyclophosphamide, doxorubicin and vincristine; EP: etoposide and platin; $\mathrm{PCl}$ : prophylactic cranial irradiation.

methylation and histone deacetylation may play a role in the progression of the disease. This observation has led investigators to initiate phase I/II trials with histone deacetylase inhibitors in combination with standard agents [128].

These are only a few examples of the trials currently running in SCLC. Inclusion of patients with SCLC in clinical trials should be encouraged, as this is the only means of improving the current standard of care. The virtual status quo since the early 1980s in the treatment of ES-SCLC (with the exception of PCI) must not lead to defeatism, but should rather be seen as a challenge for researchers and clinicians to join forces in developing new and better treatments for patients with SCLC. We owe it to our patients to continuously expand the borders of our knowledge.

\section{STATEMENT OF INTEREST}

None declared.

\section{REFERENCES}

1 Zelen M. Keynote address on biostatistics and data retrieval Cancer Chemother Rep 3 1973; 4: 31-42.

2 Stahel R, Ginsberg R, Havemann K, et al. Staging and prognostic factors in small cell lung cancer: a consensus report. Lung Cancer 1989; 5: 119-126.

3 Shepherd FA, Crowley J, Van Houtte P, et al. The International Association for the Study of Lung Cancer lung cancer staging project: proposals regarding the clinical staging of small cell lung cancer in the forthcoming (seventh) edition of the tumor, node, metastasis classification for lung cancer. J Thorac Oncol 2007; 2: 1067-1077.

4 Slotman B, Faivre-Finn C, Kramer G, et al. Prophylactic cranial irradiation in extensive small-cell lung cancer. N Engl J Med 2007; 357: 664-672.

5 Kato Y, Ferguson TB, Bennett DE, et al. Oat cell carcinoma of the lung. A review of 138 cases. Cancer 1969; 23: 517-524.

6 Agra Y, Pelayo M, Sacristan M, et al. Chemotherapy versus best supportive care for extensive small cell lung cancer. Cochrane Database Syst Rev 2003; 4: CD001990.
7 Giordano KF, Jatoi A, Adjei AA, et al. Ramifications of severe organ dysfunction in newly diagnosed patients with small cell lung cancer: contemporary experience from a single institution. Lung Cancer 2005; 49: 209-215.

8 Evans WK, Shepherd FA, Feld R, et al. VP-16 and cisplatin as first-line therapy for small-cell lung cancer. J Clin Oncol 1985; 3: 1471-1477.

9 Roth BJ, Johnson DH, Einhorn LH, et al. Randomized study of cyclophosphamide, doxorubicin, and vincristine versus etoposide and cisplatin versus alternation of these two regimens in extensive small-cell lung cancer: a phase III trial of the Southeastern Cancer Study Group. J Clin Oncol 1992; 10: 282-291.

10 Pujol JL, Carestia L, Daures JP. Is there a case for cisplatin in the treatment of small-cell lung cancer? A meta-analysis of randomized trials of a cisplatin-containing regimen versus a regimen without this alkylating agent. Br J Cancer 2000; 83: 8-15.

11 Mascaux C, Paesmans $M$, Berghmans $T$, et al. A systematic review of the role of etoposide and cisplatin in the chemotherapy of small cell lung cancer with methodology assessment and meta-analysis. Lung Cancer 2000; 30: 23-36.

12 Amarasena IU, Walters JA, Wood-Baker R, et al. Platinum versus non-platinum chemotherapy regimens for small cell lung cancer. Cochrane Database Syst Rev 2008; 4: CD006849.

13 Sundstrøm S, Bremnes RM, Kaasa S, et al. Cisplatin and etoposide regimen is superior to cyclophosphamide, epirubicin, and vincristine regimen in small-cell lung cancer: results from a randomized phase III trial with 5 years' follow-up. J Clin Oncol 2002; 20: 4665-4672.

14 Kosmidis PA, Samantas E, Fountzilas G, et al. Cisplatin/ etoposide versus carboplatin/etoposide chemotherapy and irradiation in small cell lung cancer: a randomized phase III study. Hellenic Cooperative Oncology Group for Lung Cancer Trials. Semin Oncol 1994; 21: Suppl. 6, 23-30.

15 Skarlos DV, Samantas E, Kosmidis P, et al. Randomized comparison of etoposide-cisplatin vs. etoposide-carboplatin and irradiation in small-cell lung cancer: A Hellenic Co-operative Oncology Group study. Ann Oncol 1994; 5: 601-607.

16 Souhami RL, Spiro SG, Rudd RM, et al. Five-day oral etoposide treatment for advanced small-cell lung cancer: randomized comparison with intravenous chemotherapy. J Natl Cancer Inst 1997; 89: 577-580.

17 Girling DJ. Comparison of oral etoposide and standard intravenous multidrug chemotherapy for small-cell lung cancer: a stopped multicentre randomised trial. Lancet 1996; 348: 563-566.

18 Noda K, Nishiwaki Y, Kawahara M, et al. Irinotecan plus cisplatin compared with etoposide plus cisplatin for extensive small-cell lung cancer. N Engl J Med 2002; 346: 85-91.

19 Hanna N, Bunn PA Jr, Langer C, et al. Randomized phase III trial comparing irinotecan/cisplatin with etoposide/cisplatin in patients with previously untreated extensive-stage disease small-cell lung cancer. J Clin Oncol 2006; 24: 2038-2043.

20 Hermes A, Bergman B, Bremnes R, et al. Irinotecan plus carboplatin versus oral etoposide plus carboplatin in extensive small-cell lung cancer: a randomized phase III trial. J Clin Oncol 2008; 26: 4261-4267.

21 Lara PN Jr, Natale R, Crowley J, et al. Phase III trial of irinotecan/cisplatin compared with etoposide/cisplatin in extensive-stage small-cell lung cancer: clinical and pharmacogenomic results from SWOG S0124. J Clin Oncol 2009; 27: 2530-2535.

22 Artal-Cortes A, Gomez-Codina J, Gonzalez-Larriba JL, et al. Prospective randomized phase III trial of etoposide/cisplatin versus high-dose epirubicin/cisplatin in small-cell lung cancer. Clin Lung Cancer 2004; 6: 175-183.

23 Eckardt JR, von Pawel J, Papai Z, et al. Open-label, multicenter, randomized, phase III study comparing oral topotecan/cisplatin versus etoposide/cisplatin as treatment for chemotherapy-naive 
patients with extensive-disease small-cell lung cancer. J Clin Oncol 2006; 24: 2044-2051.

24 Heigener DF, Freitag L, Eschbach C, et al. Topotecan/cisplatin (TP) compared to cisplatin/etoposide (PE) for patients with extensive disease-small cell lung cancer (ED-SCLC): final results of a randomised phase III trial. J Clin Oncol 2008; 26: Suppl. 15, 7513.

25 Socinski MA, Weissman C, Hart LL, et al. randomized phase II trial of pemetrexed combined with either cisplatin or carboplatin in untreated extensive-stage small-cell lung cancer. J Clin Oncol 2006; 24: 4840-4847.

26 Niell HB, Herndon JE 2nd, Miller AA, et al. Randomized phase III intergroup trial of etoposide and cisplatin with or without paclitaxel and granulocyte colony-stimulating factor in patients with extensive-stage small-cell lung cancer: Cancer and Leukemia Group B Trial 9732. J Clin Oncol 2005; 23: 3752-3759.

27 Loehrer PJ Sr, Ansari R, Gonin R, et al. Cisplatin plus etoposide with and without ifosfamide in extensive small-cell lung cancer: a Hoosier Oncology Group study. J Clin Oncol 1995; 13: 2594-2599.

28 Pujol JL, Daures JP, Riviere A, et al. Etoposide plus cisplatin with or without the combination of 4'-epidoxorubicin plus cyclophosphamide in treatment of extensive small-cell lung cancer: a French Federation of Cancer Institutes multicenter phase III randomized study. J Natl Cancer Inst 2001; 93: 300-308.

29 de Jong WK, Groen HJM, Koolen MGJ, et al. Phase III study of cyclophosphamide, doxorubicin, and etoposide compared with carboplatin and paclitaxel in patients with extensive disease small-cell lung cancer. Eur J Cancer 2007; 43: 2345-2350.

30 Baka S, Califano R, Ferraldeschi R, et al. Phase III randomised trial of doxorubicin-based chemotherapy compared with platinum-based chemotherapy in small-cell lung cancer. $\mathrm{Br} J$ Cancer 2008; 99: 442-447.

31 Torti FM, Bristow MM, Lum BL, et al. Cardiotoxicity of epirubicin and doxorubicin: assessment by endomyocardial biopsy. Cancer Res 1986; 46: 3722-3727.

32 Ohe Y, Negoro S, Matsui K, et al. Phase I-II study of amrubicin and cisplatin in previously untreated patients with extensivestage small-cell lung cancer. Ann Oncol 2005; 16: 430-436.

33 Yana T, Negoro S, Takada M, et al. Phase II study of amrubicin in previously untreated patients with extensive-disease small cell lung cancer: West Japan Thoracic Oncology Group (WJTOG) study. Invest New Drugs 2007; 25: 253-258.

34 AMR PH GL 2007 CL 001 Phase 3 Trial in Patients with Small Cell Lung Cancer after Failure of First-Line Chemotherapy. www.clinicaltrials.gov/ct2/show/NCT00547651 Date last updated: September 25, 2009. Date last accessed: October 9, 2009.

35 Phase 3 Study of Amrubicin with Cisplatin versus EtoposideCisplatin for Extensive Disease Small Cell Lung Cancer. www. clinicaltrials.gov/ct2/show/NCT00660504 Date last updated: August 19, 2009. Date last accessed: October 9, 2009.

36 Innocenti F, Kroetz DL, Schuetz E, et al. Comprehensive pharmacogenetic analysis of irinotecan neutropenia and pharmacokinetics. J Clin Oncol 2009; 27: 2604-2614.

37 Quoix E, Breton J-L, Gervais R, et al. A randomised phase II study of the efficacy and safety of intravenous topotecan in combination with either cisplatin or etoposide in patients with untreated extensive disease small-cell lung cancer. Lung Cancer 2005; 49: 253-261.

38 Lee DH, Kim S-W, Suh C, et al. Belotecan, new camptothecin analogue, is active in patients with small-cell lung cancer: results of a multicenter early phase II study. Ann Oncol 2008; 19: 123-127.

39 Trial of Belotecan/Cisplatin in Chemotherapy Naive Small Cell Lung Cancer Patient (COMBAT). www.clinicaltrials.gov/ct2/ show/NCT00826644 Date last updated: January 21, 2009. Date last accessed: May 14, 2009.

40 Socinski MA, Smit EF, Lorigan P, et al. Phase III study of pemetrexed plus carboplatin (PC) versus etoposide plus carboplatin (EC) in chemonaive patients (pts) with extensive-stage disease small cell lung cancer (ED-SCLC): interim results. J Clin Oncol 2008; 26: 400S.

41 Smit EF, Fokkema E, Biesma B, et al. A phase II study of paclitaxel in heavily pretreated patients with small-cell lung cancer. Br J Cancer 1998; 77: 347-351.

42 Mavroudis D, Papadakis E, Veslemes M, et al. A multicenter randomized clinical trial comparing paclitaxel-cisplatin-etoposide versus cisplatin-etoposide as first-line treatment in patients with small-cell lung cancer. Ann Oncol 2001; 12: 463-470.

43 Klasa R, Murray N, Coldman A. Dose-intensity meta-analysis of chemotherapy regimens in small-cell carcinoma of the lung. J Clin Oncol 1991; 9: 499-508.

44 Klasa R, Murray N, Coldman A. Dose intensity (DI) analysis of chemotherapy in small cell carcinoma of the lung (SCCL). Proc Am Soc Clin Oncol 1987; 6: 173.

45 Ihde DC, Mulshine JL, Kramer BS, et al. Prospective randomized comparison of high-dose and standard-dose etoposide and cisplatin chemotherapy in patients with extensive-stage smallcell lung cancer. J Clin Oncol 1994; 12: 2022-2034.

46 Pujol JL, Douillard JY, Riviere A, et al. Dose-intensity of a fourdrug chemotherapy regimen with or without recombinan human granulocyte-macrophage colony-stimulating factor in extensive-stage small-cell lung cancer: a multicenter randomized phase III study. J Clin Oncol 1997; 15: 2082-2089.

47 Ardizzoni A, Tjan-Heijnen VC, Postmus PE, et al. Standard versus intensified chemotherapy with granulocyte colony-stimulating factor support in small-cell lung cancer: a prospective European Organization for Research and Treatment of Cancer-Lung Cancer Group Phase III Trial-08923. J Clin Oncol 2002; 20: 3947-3955.

48 Berghmans T, Paesmans M, Lafitte JJ, et al. Role of granulocyte and granulocyte-macrophage colony-stimulating factors in the treatment of small-cell lung cancer: a systematic review of the literature with methodological assessment and meta-analysis. Lung Cancer 2002; 37: 115-123.

49 Lorigan P, Woll PJ, O'Brien ME, et al. Randomized phase III trial of dose-dense chemotherapy supported by whole-blood hematopoietic progenitors in better-prognosis small-cell lung cancer. J Natl Cancer Inst 2005; 97: 666-674.

50 Leyvraz S, Pampallona S, Martinelli G, et al. A threefold dose intensity treatment with ifosfamide, carboplatin, and etoposide for patients with small cell lung cancer: a randomized trial. J Natl Cancer Inst 2008; 100: 533-541.

51 Giaccone G, Dalesio O, McVie GJ, et al. Maintenance chemotherapy in small-cell lung cancer: long-term results of a randomized trial. European Organization for Research and Treatment of Cancer Lung Cancer Cooperative Group. J Clin Oncol 1993; 11: 1230-1240.

52 Schiller JH, Adak S, Cella D, et al. Topotecan versus observation after cisplatin plus etoposide in extensive-stage small-cell lung cancer: E7593 - a phase III trial of the Eastern Cooperative Oncology Group. J Clin Oncol 2001; 19: 2114-2122.

53 Sculier JP, Berghmans T, Castaigne C, et al. Maintenance chemotherapy for small cell lung cancer: a critical review of the literature. Lung Cancer 1998; 19: 141-151.

54 Bozcuk H, Artac M, Ozdogan M, et al. Does maintenance/ consolidation chemotherapy have a role in the management of small cell lung cancer (SCLC)? A metaanalysis of the published controlled trials. Cancer 2005; 104: 2650-2657.

55 Rinaldi M, Belvedere O, Cauchi C, et al. Maintenance chemotherapy in non-small cell lung cancer. Ann Oncol 2006; 17: Suppl. 2, ii67-ii70.

56 Postmus PE, Scagliotti G, Groen HJ, et al. Standard versus alternating non-cross-resistant chemotherapy in extensive small cell lung cancer: an EORTC phase III trial. Eur J Cancer 1996; 32A: 1498-1503.

57 Akl EA, Kamath G, Kim SY, et al. Oral anticoagulation for prolonging survival in patients with cancer. Cochrane Database Syst Rev 2007; 2: CD006466. 
58 Akl EA, van Doormaal FF, Barba M, et al. Parenteral anticoagulation may prolong the survival of patients with limited small cell lung cancer: a Cochrane systematic review. J Exp Clin Cancer Res 2008; 27: 4.

59 A Study of Standard Treatment +/- Enoxaparin in Small Cell Lung Cancer (RASTEN). www.clinicaltrials.gov/ct2/show/ NCT00717938 Date last updated: September 16, 2009. Date last accessed: October 9, 2009.

60 Dalteparin in Preventing Blood Clots in Patients with Lung Cancer. www.clinicaltrials.gov/ct2/show/NCT00519805 Date last updated: October 6, 2009. Date last accessed: October 9, 2009.

61 Khanzada UK, Pardo OE, Meier C, et al. Potent inhibition of small-cell lung cancer cell growth by simvastatin reveals selective functions of Ras isoforms in growth factor signalling. Oncogene 2006; 25: 877-887.

62 Weiss RH, Ramirez AL, Joo A. Short-term pravastatin mediates growth inhibition and apoptosis, independently of Ras, via the signaling proteins p $27^{\mathrm{Kip} 1}$ and PI3 kinase. J Am Soc Nephrol 1999; 10: $1880-1890$.

63 Ravi RK, Weber E, McMahon M, et al. Activated Raf-1 causes growth arrest in human small cell lung cancer cells. J Clin Invest 1998; 101: 153-159.

64 Etoposide and Cisplatin or Carboplatin as First-Line Chemotherapy with or Without Pravastatin in Treating Patients with Small Cell Lung Cancer. www.clinicaltrials.gov/ ct2/show/NCT00433498 Date last updated: February 6, 2009. Date last accessed: May 14, 2009.

65 Bentzion D, Lipatov O, Polyakov I, et al. A phase II study of picoplatin (pico) as second-line therapy for patients (pts) with small cell lung cancer (SCLC) who have resistant or refractory disease or have relapsed within 180 days of completing first-line, platinum (plat)-containing chemotherapy. J Clin Oncol 2007; 25: Suppl. 18, 7722.

66 Treat J, Schiller J, Quoix E, et al. ZD0473 treatment in lung cancer: an overview of the clinical trial results. Eur J Cancer 2002; 38: Suppl. 8, S13-S18.

67 Study of Picoplatin Efficacy After Relapse (SPEAR). www. clinicaltrials.gov/ct2/show/NCT00465491 Date last updated: April 13, 2009. Date last accessed: May 14, 2009.

68 A Phase I/II Study of Carboplatin and Etoposide with or without Obatoclax in Extensive-Stage Small Cell Lung Cancer (ES-SCLC). www.clinicaltrials.gov/ct2/show/NCT00682981 Date last updated: September 14, 2009. Date last accessed: October 9, 2009.

69 Obatoclax Mesylate and Topotecan in Treating Patients with Relapsed or Refractory Small Cell Lung Cancer or Advanced Solid Tumors. www.clinicaltrials.gov/ct2/show/NCT00521144 Date last updated: July 7, 2009. Date last accessed: October 9, 2009

70 Temozolomide for Relapsed Sensitive or Refractory Small Cell Lung Cancer. www.clinicaltrials.gov/ct2/show/NCT00740636 Date last updated: September 18, 2009. Date last accessed: October 9, 2009.

71 von Pawel J, Schiller JH, Shepherd FA, et al. Topotecan versus cyclophosphamide, doxorubicin, and vincristine for the treatment of recurrent small-cell lung cancer. J Clin Oncol 1999; 17: 658-667.

72 Rosti G, Bevilacqua G, Bidoli P, et al. Small cell lung cancer. Ann Oncol 2006; 17: Suppl. 2, ii5-ii10.

73 O'Brien ME, Ciuleanu TE, Tsekov $\mathrm{H}$, et al. Phase III trial comparing supportive care alone with supportive care with oral topotecan in patients with relapsed small-cell lung cancer. J Clin Oncol 2006; 24: 5441-5447.

74 Eckardt JR, von Pawel J, Pujol JL, et al. Phase III study of oral compared with intravenous topotecan as second-line therapy in small-cell lung cancer. J Clin Oncol 2007; 25: 2086-2092.

75 von Pawel J, Gatzemeier U, Pujol JL, et al. Phase II comparator study of oral versus intravenous topotecan in patients with chemosensitive small-cell lung cancer. J Clin Oncol 2001; 19: $1743-1749$.
76 Hoang T, Kim K, Jaslowski A, et al. Phase II study of second-line gemcitabine in sensitive or refractory small cell lung cancer. Lung Cancer 2003; 42: 97-102.

77 van der Lee I, Smit EF, van Putten JW, et al. Single-agent gemcitabine in patients with resistant small-cell lung cancer. Ann Oncol 2001; 12: 557-561.

78 Masters GA, Declerck L, Blanke C, et al. Phase II trial of gemcitabine in refractory or relapsed small-cell lung cancer: Eastern Cooperative Oncology Group trial 1597. J Clin Oncol 2003; 21: 1550-1555.

79 Masuda N, Fukuoka M, Kusunoki Y, et al. CPT-11: a new derivative of camptothecin for the treatment of refractory or relapsed small-cell lung cancer. J Clin Oncol 1992; 10: 1225-1229.

80 Joos G, Schallier D, Pinson P, et al. Paclitaxel (PTX) as second line treatment in patients (pts) with small cell lung cancer (SCLC) refractory to carboplatin - etoposide: a multicenter phase II study. J Clin Oncol 2004; 22: Suppl. 14, 7211.

81 Furuse K, Kubota K, Kawahara M, et al. Phase II study of vinorelbine in heavily previously treated small cell lung cancer. Oncology 1996; 53: 169-172.

82 Jassem J, Karnicka-Mlodkowska H, van Pottelsberghe C, et al. Phase II study of vinorelbine (Navelbine) in previously treated small cell lung cancer patients. EORTC Lung Cancer Cooperative Group. Eur J Cancer 1993; 29A: 1720-1722.

83 Hanna NH, Ansari R, Bhatia S, et al. Pemetrexed in patients (pts) with relapsed small cell lung cancer (SCLC): a phase II study from the Hoosier Oncology Group. J Clin Oncol 2006; 24: Suppl. $18,7063$.

84 Gronberg BH, Bremnes RM, Aasebo U, et al. A prospective phase II study: high-dose pemetrexed as second-line chemotherapy in small-cell lung cancer. Lung Cancer 2009; 63: 88-93.

85 Socinski MA, Raju RN, Neubauer M, et al. Pemetrexed in relapsed small-cell lung cancer and the impact of shortened vitamin supplementation lead-in time: results of a phase II trial. J Thorac Oncol 2008; 3: 1308-1316.

86 Onoda S, Masuda N, Seto T, et al. Phase II trial of amrubicin for treatment of refractory or relapsed small-cell lung cancer: Thoracic Oncology Research Group study 0301. J Clin Oncol 2006; 24: 5448-5453.

87 Kato T, Nokihara H, Ohe $\mathrm{Y}$, et al. Phase II trial of amrubicin in patients with previously treated small cell lung cancer (SCLC). J Clin Oncol 2006; 24: Suppl. 18, 7061.

88 Kudoh S, Yoshimura N, Kimura T, et al. A phase II trial of amrubicin (AMR) for recurrent or refractory small cell lung cancer (SCLC). J Clin Oncol 2006; 24: Suppl. 18, 17053.

89 Ettinger DS, Jotte RM, Gupta V, et al. A phase II trial of singleagent amrubicin (AMR) in patients with extensive disease small cell lung cancer (ED-SCLC) that is refractory or progressive within 90 days of completion of first-line platinum-based chemotherapy. J Clin Oncol 2008; 26: Suppl. 15, 8041.

90 Inoue A, Sugawara S, Yamazaki K, et al. Randomized phase II trial comparing amrubicin with topotecan in patients with previously treated small-cell lung cancer: North Japan Lung Cancer Study Group trial 0402. J Clin Oncol 2008; 26: 5401-5406.

91 Perry MC, Eaton WL, Propert KJ, et al. Chemotherapy with or without radiation therapy in limited small-cell carcinoma of the lung. N Engl J Med 1987; 316: 912-918.

92 Jeremic B, Shibamoto Y, Nikolic N, et al. Role of radiation therapy in the combined-modality treatment of patients with extensive disease small-cell lung cancer: a randomized study. J Clin Oncol 1999; 17: 2092-2099.

93 Nederlands Trial RegisterRandomised Trial on Chest Irradiation in Extensive Disease Small Cell Lung Cancer. www.trialregister. $\mathrm{nl} /$ trialreg/admin/rctview.asp?TC $=1527$ Date last updated: January 21, 2009. Date last accessed: May 14, 2009.

94 Slotman BJ, Mauer ME, Bottomley A, et al. Prophylactic cranial irradiation in extensive disease small-cell lung cancer: short-term 
health-related quality of life and patient reported symptoms: results of an international phase III randomized controlled trial by the EORTC Radiation Oncology and Lung Cancer Groups. J Clin Oncol 2009; 27: 78-84.

95 Moore AM, Einhorn LH, Estes D, et al. Gefitinib in patients with chemo-sensitive and chemo-refractory relapsed small cell cancers: a Hoosier Oncology Group phase II trial. Lung Cancer 2006; 52: 93-97.

96 Dy GK, Miller AA, Mandrekar SJ, et al. A phase II trial of imatinib (ST1571) in patients with c-kit expressing relapsed small-cell lung cancer: a CALGB and NCCTG study. Ann Oncol 2005; 16: 1811-1816.

97 Krug LM, Crapanzano JP, Azzoli CG, et al. Imatinib mesylate lacks activity in small cell lung carcinoma expressing c-kit protein: a phase II clinical trial. Cancer 2005; 103: 2128-2131.

98 Johnson BE, Fischer T, Fischer B, et al. Phase II study of imatinib in patients with small cell lung cancer. Clin Cancer Res 2003; 9: 5880-5887.

99 Schneider BJ, Gadgeel S, Ramnath N, et al. Phase II trial of imatinib maintenance therapy after irinotecan and cisplatin in patients with c-kit positive extensive-stage small cell lung cancer (ES SCLC). J Clin Oncol 2006; 24: Suppl. 18, 17089.

100 Spigel DR, Hainsworth JD, Simons L, et al. Irinotecan, carboplatin, and imatinib in untreated extensive-stage small-cell lung cancer: a phase II trial of the Minnie Pearl Cancer Research Network. J Thorac Oncol 2007; 2: 854-861.

101 Sandler A, Szwaric S, Dowlati A, et al. A phase II study of cisplatin (P) plus etoposide (E) plus bevacizumab (B) for previously untreated extensive stage small cell lung cancer (SCLC) (E3501): a trial of the Eastern Cooperative Oncology Group. J Clin Oncol 2007; 25: Suppl. 18, 7564.

102 Ready N, Dudek AZ, Wang XF, et al. CALGB 30306: a phase II study of cisplatin (C), irinotecan (I) and bevacizumab (B) for untreated extensive stage small cell lung cancer (ES-SCLC). J Clin Oncol 2007; 25: Suppl. 18, 7563.

103 Jalal SI, Bhatia S, Einhorn LH, et al. Paclitaxel (P) plus bevacizumab (B) in patients (pts) with chemosensitive relapsed small cell lung cancer (SCLC): a safety, feasibility and efficacy trial from the Hoosier Oncology Group. J Clin Oncol 2008; 26: Suppl. 15, 19013.

104 Arnold AM, Seymour L, Smylie M, et al. Phase II study of vandetanib or placebo in small-cell lung cancer patients after complete or partial response to induction chemotherapy with or without radiation therapy: National Cancer Institute of Canada Clinical Trials Group study BR.20. J Clin Oncol 2007; 25: 4278-4284.

105 Gitlitz BJ, Glisson BS, Moon J, et al. Sorafenib in patients with platinum (plat) treated extensive stage small cell lung cancer (ESCLC): a SWOG (S0435) phase II trial. J Clin Oncol 2008; 26: Suppl. 15, 8039 .

106 Pujol JL, Breton JL, Gervais R, et al. Phase III double-blind, placebocontrolled study of thalidomide in extensive-disease small-cell lung cancer after response to chemotherapy: an intergroup study FNCLCC cleo04 IFCT 00-01. J Clin Oncol 2007; 25: 3945-3951.

107 Lee SM, James L, Buchler T, et al. Phase II trial of thalidomide with chemotherapy and as maintenance therapy for patients with poor prognosis small-cell lung cancer. Lung Cancer 2008; 59: 364-368.

108 Ramalingam SS, Mack PC, Vokes EE, et al. Cediranib (AZD2171) for the treatment of recurrent small cell lung cancer (SCLC): a California Consortium phase II study (NCI \# 7097). J Clin Oncol 2008; 26: Suppl. 15, 8078.

109 Haeder M, Rotsch M, Bepler G, et al. Epidermal growth factor receptor expression in human lung cancer cell lines. Cancer Res 1988; 48: 1132-1136.

110 Sandler A, Gray R, Perry MC, et al. Paclitaxel-carboplatin alone or with bevacizumab for non-small-cell lung cancer. $N$ Engl $J$ Med 2006; 355: 2542-2550.
111 Wedge SR, Ogilvie DJ, Dukes M, et al. ZD6474 inhibits vascular endothelial growth factor signaling, angiogenesis, and tumor growth following oral administration. Cancer Res 2002; 62: 46454655.

112 Dowlati A, Subbiah S, Cooney M, et al. Phase II trial of thalidomide as maintenance therapy for extensive stage small cell lung cancer after response to chemotherapy. Lung Cancer 2007; 56: 377-381.

113 Lee SM, Woll PJ, James LE, et al. A phase III randomised, double blind, placebo controlled trial of etoposide/carboplatin with or without thalidomide in advanced small cell lung cancer. J Thorac Oncol 2007; 2: Suppl. 4, S306.

114 Pandya KJ, Dahlberg S, Hidalgo M, et al. A randomized, phase II trial of two dose levels of temsirolimus (CCI-779) in patients with extensive-stage small-cell lung cancer who have responding or stable disease after induction chemotherapy: a trial of the Eastern Cooperative Oncology Group (E1500). J Thorac Oncol 2007; 2: 1036-1041.

115 Micke P, Basrai M, Faldum A, et al. Characterization of c-kit expression in small cell lung cancer: prognostic and therapeutic implications. Clin Cancer Res 2003; 9: 188-194.

116 Krystal GW, Honsawek S, Litz J, et al. The selective tyrosine kinase inhibitor STI571 inhibits small cell lung cancer growth. Clin Cancer Res 2000; 6: 3319-3326.

117 Michael M, Babic B, Khokha R, et al. Expression and prognostic significance of metalloproteinases and their tissue inhibitors in patients with small-cell lung cancer. J Clin Oncol 1999; 17: 18021808.

118 Shepherd FA, Giaccone G, Seymour L, et al. Prospective, randomized, double-blind, placebo-controlled trial of marimastat after response to first-line chemotherapy in patients with smallcell lung cancer: a trial of the National Cancer Institute of CanadaClinical Trials Group and the European Organization for Research and Treatment of Cancer. J Clin Oncol 2002; 20: 4434-4439.

119 Rigas JR, Denham CA, Rinaldi D, et al. Adjuvant targeted therapy in unresectable lung cancer: the results of two randomized placebo-controlled trials of BAY 12-9566, a matrix metalloproteinase inhibitor (MMPI). Lung Cancer 2003; 41: Suppl. 2, S34-S34.

120 Giaccone G, Debruyne C, Felip E, et al. Phase III study of adjuvant vaccination with $\mathrm{Bec} 2 /$ bacille Calmette-Guerin in responding patients with limited-disease small-cell lung cancer (European Organisation for Research and Treatment of Cancer 08971-08971B; Silva Study). J Clin Oncol 2005; 23: 6854-6864.

121 Ziegler A, Luedke GH, Fabbro D, et al. Induction of apoptosis in small-cell lung cancer cells by an antisense oligodeoxynucleotide targeting the Bcl-2 coding sequence. J Natl Cancer Inst 1997; 89: 1027-1036.

122 Zangemeister-Wittke U, Schenker T, Luedke GH, et al. Synergistic cytotoxicity of bcl-2 antisense oligodeoxynucleotides and etoposide, doxorubicin and cisplatin on small-cell lung cancer cell lines. Br J Cancer 1998; 78: 1035-1042.

123 Rudin CM, Salgia R, Wang X, et al. Randomized phase II study of carboplatin and etoposide with or without the bcl-2 antisense oligonucleotide oblimersen for extensive-stage small-cell lung cancer: CALGB 30103. J Clin Oncol 2008; 26: 870-876.

124 Simon GR, Turrisi A. Management of small cell lung cancer: ACCP evidence-based clinical practice guidelines (2nd edition). Chest 2007; 132: Suppl. 3, 324S-339S.

125 Sorensen M, Felip E. Small-cell lung cancer: ESMO clinical recommendations for diagnosis, treatment and follow-up. Ann Oncol 2008; 19: Suppl. 2, ii41-ii42.

126 National Collaborating Centre for Acute CareLung Cancer. The Diagnosis and Treatment of Lung Cancer. London, National Institute for Clinical Excellence, 2005. www.nice.org.uk/ nicemedia/pdf/CG024niceguideline.pdf. Date last updated: February 2005. Date last accessed: May 14, 2009. 
127 National Comprehensive Cancer NetworkNCCN Clinical Practice Guidelines in Oncology. Small Cell lung cancer. www. nccn.org/professionals/physician_gls/PDF/sclc.pdf Date last accessed: May 14, 2009.
128 Carboplatin and Etoposide in Combination with Vorinostat for Patients with Extensive Stage Small Cell Lung Cancer. www. clinicaltrials.gov/ct2/show/NCT00702962 Date last updated: February 3, 2009. Date last accessed: May 14, 2009. 